\title{
A WHO JÓL-LÉT KÉRDŐÍV RÖVIDÍTETT (WBI-5) MAGYAR VÁLTOZATÁNAK VALIDÁLÁSA A HUNGAROSTUDY 2002 ORSZÁGOS LAKOSSÁGI EGÉSZSÉGFELMÉRÉS ALAPJÁN
}

\author{
SUSÁNSZKY ÉVA* - KONKOLŸ THEGE BARNA - \\ STAUDER ADRIENNE - KOPP MÁRIA
}

Semmelweis Egyetem, Magatartástudományi Intézet, Budapest

(Beérkezett: 2006. július 20.; elfogadva: 2006. július 24.)

\begin{abstract}
Írásunk a WHO Jól-lét Kérdőív 5 tételes (WBI-5) rövidített magyar verziójának hazai adaptálását mutatja be. A mérőeszköz validálása a Hungarostudy 2002 országos lakossági egészségfelmérés alapján készült. A vizsgálat 12668 főre terjedt ki, a minta életkor, nem és lakóhely szerint reprezentálja a felnótt magyar népességet. A validáláshoz a Rövidített Beck Depresszió Kérdőívet, a Beck-féle Reménytelenség Skála három tételét, a Kórházi Szorongás és Depresszió Skála szorongás alskáláját (HAS), a rövidített Maastricht Vitális Kimerültség Kérdőívet, a rövidített Stressz és Megküzdés Kérdôív Életcél és Kapcsolatok alskálájának 7 kérdését, valamint az egészségi állapot önbecslését használtuk fel. Az öttételes WHO Általános Jól-lét Skála belsố megbízhatósága kiváló (Cronbach-alfa: 0,85). A mérôeszköz rotálatlan fốkomponens-elemzése is megerősítette a kérdôív homogenitását. A kérdốiv az elvárásoknak megfelelóen közepesen erốs, negatív kapcsolatban állt mind a Rövidített Beck Depresszió Kérdőív értékével, mind a szorongást mérő HAS 7 tételének összpontszámával és a reménytelenséggel. Kérdőívünk összpontszáma hasonló erősségú, pozitív kapcsolatban állt mind a válaszadó önmagához, mind másokhoz viszonyított szubjektív egészségi állapotával, továbbá az élet értelme-konstruktummal. A kérdóív magyar változata megbízható és érvényes mérôeszköznek tekinthetô a pozitív életminőség vizsgálatakor.
\end{abstract}

Kulcsszavak: WHO Jól-lét Skála, Hungarostudy 2002 lakossági egészségfelmérés

Az egészséggel kapcsolatos életminóség-vizsgálatok egyrészt a szubjektív tapasztalatokra, az önértékelésre alapoznak, másrészt pedig egy többdimenziós megközelítés alapján vizsgálódnak, amely a pszichológiai, fi-

\footnotetext{
* Levelezố szerző: Susánszky Éva, Semmelweis Egyetem, Magatartástudományi Intézet, 1089 Budapest, Nagyvárad tér 4. E-mail: suseva@net.sote.hu
} 
zikai és szociális aspektusokat is figyelembe veszi. A Jól-lét Skála az egyik leggyakrabban használt mérőeszköz, amelyet a pszichológiai jól-lét önértékelésen alapuló mérésére használnak a klinikai vagy a követéses vizsgálatokban.

A WHO Jól-lét Index (Well-Being Index, WBI) kidolgozása 1982-ben történt egy nemzetközi kutatás keretében, amely a cukorbetegeknél alkalmazott különbözó terápiás eljárások hatékonyságát vizsgálta az életminőség szempontjából, a betegek szubjektív megítélése alapján. A fejlesztés célja az volt, hogy ne csak a negatív életminóség-mutatókat (pl. depresszió, szorongás) vegyék figyelembe a vizsgálat során, hanem a pozitívakat is. A kérdőív a Zung-féle depresszió, szorongás és a pszichés distressz önbecslésére kidolgozott kérdốiven alapult, és ehhez illesztettek új, a pozitív jól-lét mérésére kidolgozott kérdéseket. A kezdeti kérdóív 28 tételból állt, majd a nemzetközi adatok (francia, német, brit) értékelése alapján 22 tételesre módosították. Ez a rövidebb változat négy alskálát (depresszió, szorongás, energia, jól-lét) tartalmazott. A rövidítéssel egy idóben felmerült a kérdốiv rutinszerú használatának igénye az egészségügyi ellátásban, amely a további rövidítés szükségességét vetette fel. A következó tíztételes változat a jól-lét negatív és pozitív aspektusait egyetlen dimenzióban egyesítette. 1996-ban Bech és munkatársai bemutattak egy tíztételes skálaverziót (Bech és mtsai 1996), majd ugyanebben az évben Bech publikált egy öttételes méróeszközt (Bech 1996). A tíz- és az öttételes skálák elemei a 22 tételes változatban is megvannak. A tíztételes változat a jól-lét negatív és pozitív aspektusait egyetlen dimenzióban egyesítette.

\section{MÓDSZER}

\section{Minta}

Jelen tanulmány egy 2002-ben végzett országos reprezentatív felmérés, a "Hungarostudy 2002" adataira támaszkodik. A „Hungarostudy 2002” célja a felnótt magyar lakosság egészségi állapotának és bio-pszicho-szociális jellemzóinek feltérképezése volt. A véletlenszerúen kiválasztott, 12668 fốs minta életkor, nem és lakóhely (150 kisrégió) szerint reprezentálja a magyar népességet. A mintaválasztás a 2001-ben a Cenzus szerint módosított Népességnyilvántartáson alapult. Minden 10000 fónél nagyobb népességgel rendelkező település bekerült a mintába, a 10000 főnél kevesebb lakost számláló települések egy véletlenszerú kiválasztás alapján kerültek be a mintába. A visszautasítás aránya 17,7 százalékos volt. A nagyobb településeken (városokban) a részvételt elutasítók ará- 
nya magasabb volt, mint a falvakban. Minden személy helyett, aki visszautasította a kérdóív kitöltését, egy ugyanazon a településen lakó, hasonló életkorú és nemú személlyel helyettesítettek a pótlistáról. A kérdezóbiztosok a feladatra kiképzett körzeti védónók voltak, akik a kérdezetteket lakásukban keresték fel. A kérdốív kitöltése átlagosan 1 órát vett igénybe (Rózsa és mtsai 2003).

Általános jól-lét

\section{Mérôeszközök}

Validálni kívánt méróeszközünk, a WHO Általános Jól-lét Skálájának (Bech és mtsai 1996) 5 tételes változata a személyek általános közérzetéról kíván információt nyújtani az elmúlt kéthetes időszak alapján. Az eredeti, 6 fokú skála leegyszerúsítését epidemiológiai vizsgálatunk tesztbattériájának rendkívüli összetettsége indokolta. Így a teszt olyan, 4 fokú skálán (egyáltalán nem jellemző / alig jellemző / jellemző / teljesen jellemzó) megítélhetó állításokat tartalmaz, mint hogy "Az elmúlt két hét során érezte magát vidámnak és jókedvúnek?” vagy "Az elmúlt két hét során érezte magát ébredéskor frissnek és kipihentnek?". Noha az utolsó tétel szerkezete valamelyest eltér a többitól, az itemanalízis (lásd az eredmények ismertetésénél) eredményeiból következtetve ez mégsem okoz a válaszadóknak nehézséget. Méróeszközünk fordított tételt nem tartalmaz, a nagyobb pontszámok jelentik a pozitívabb, kedvezóbb pszichológiai állapotot. Mivel skálánk 0-3-ig terjedt, az elérhetố pontszámok 0 és 15 pont között változhattak.

\section{Szorongás}

A szorongásos tüneteket a Kórházi Szorongás és Depresszió Skála 7 tételes szorongás alskálájával (HAS) mértük (Hospital Anxiety and Depression Scale ${ }^{1}$ ) (Zigmond és Snaith 1983). A kérdezettek egy négyfokú skála segítségével minősíthették állapotukat. A teszt igen nagy nemzetközi elismertségnek örvend, mivel rövidsége ellenére is érvényes és megbízható méróeszköznek bizonyult, mely kiküszöbölte az eddigi hasonló célú kérdóívek számos hibáját. Így példának okáért, mivel testi tünetekre való rákérdezés nélkül próbálja felmérni a szorongásszintet, csökken a "téves riasztások" száma az organikus betegeknél; illetve érzékenyebb már a közepes szintú tünetekre is (Herrmann 1997), ami egy, a mienkhez hasonló nagyságú, normatív minta esetén kiemelten fontos. A teszt belsố konzisztenciája mintánkban jónak mutatkozott (Cronbach-alfa = 0,83).

\footnotetext{
${ }^{1}$ HADS copyright (C R. P. Snaith and A. S. Zigmond, 1983, 1992, 1994. Reproduced by
} permission of nferNelson Publishing Company Ltd., London, UK 
Reménytelenség

A Beck-féle Reménytelenség Skála (Beck és mtsai 1974) magyar változatának (Perczel-Forintos és mtsai 2001) három tételét alkalmaztuk a reménytelenség szintjének felbecsülésére, melyeket a válaszadók négyfokú skálán ítélhettek meg. Jellemzó példa: „Sosem fognak úgy alakulni a dolgok, ahogy én akarom". Az itemcsoport belsó megbízhatósága rövidsége ellenére is igen jó volt (Cronbach-alfa $=0,83$ ).

\section{Vitális kimerültség}

A vitális kimerültség fáradtságból, energiahiányból, fokozott irritábilitásból összeálló komplex érzelmi élmény (Bagés és mtsai 2000), mely nemcsak a kardiovaszkuláris megbetegedésekkel (Bagés és mtsai 1999), hanem definíciójából fakadóan a személy általános közérzetével is evidens módon kapcsolatban áll. Az ezt mérô, öttételes, dichotóm skálájú Rövidített Maastricht Vitális Kimerültség Kérdôív (Kopp és mtsai 1998) tételei közt olyanok szerepelnek, mint hogy "Gyakran érzi fáradtnak magát?" vagy „Jobban irritálják apróbb dolgok, mint régen?”. Az itemcsoport belsó megbízhatósága jónak bizonyult (Cronbach-alfa $=0,78)$.

Depressziós tünetegyüttes

A 9 tételes, négyfokú Likert-skálával rendelkező Rövidített Beck Depreszszió Kérdớiv a depresszió olyan tüneteire kérdez rá, mint a szociális visszahúzódás, döntésképtelenség, alvászavar, fáradékonyság, túlzott aggódás a testi tünetek miatt, munkaképtelenség, pesszimizmus, az elégedettség és az öröm hiánya, valamint önvádlás (Rózsa és mtsai 2001). A magasabb pontszámok több depressziós tünetre utalnak. A kérdőív belsó megbízhatósága mintánkban is megfeleló volt (Cronbach-alfa $=0,85$ ).

\section{Az élet értelme}

Az élet értelmességének megélt szintjét a Rövidített Stressz és Megküzdés Kérdôív (Rahe és Tolles 2002) magyar változatának (Rózsa és mtsai 2005) Életcél és Kapcsolatok alskálájából vett 7 kérdéssel mértük. A háromfokú skálával rendelkezó tételek között olyanok szerepelnek, mint pl. „Úgy érzem, életem egy nagyobb terv része”, vagy „Meg vagyok békélve a helyemmel az életben". A méróeszköz belsố megbízhatósága mintánkban elfogadható volt (Cronbach-alfa $=0,67)$.

Az egészségi állapot önbecslése

Az utóbbi években számos vizsgálat bizonyította az egészségi állapot önbecslésének fontosságát (Idler és Benyamini 1997), ezért vizsgálatunkba ezt a változót is bevontuk, mint a szubjektív jóllét egyik kiemelkedő fon- 
tosságú meghatározóját. Két kérdést tettünk fel: „Összességében hogyan minősíti saját egészségi állapotát?” és „Kortársaihoz hasonlítva hogyan minósíti saját egészségi állapotát?". A két kérdést ötfokozatú, a nagyon rossztól a kiválóig terjedó skálán kellett a válaszadóknak megítélniük.

A statisztikai elemzéseket az SPSS 13.0 programcsomaggal végeztük (SPSS, Chicago, IL). Két csoport összehasonlítására független mintás tpróbát, kettőnél több csoportéra egy szempontos varianciaanalízist használtunk. A hatásméret kifejezésére a Cohen-féle d-értéket számítottuk ki egy, a világhálón szabadon használható alkalmazás segítségével (http:/ /davidmlane.com/hyperstat/effect_size.html). A konvergens és divergens validitást elemzố vizsgálatoknál parciális korrelációs együtthatókkal dolgoztunk, az „r" $\mathrm{r}^{\prime}$-ek tehát mindenütt erre utalnak.

\section{EREDMÉNYEK}

Az öttételes WHO Általános Jól-lét Skála belsố megbízhatósága rövidsége ellenére is kiváló: a Cronbach-alfa értéke 0,85 volt. Egy kisebb, kényelmi mintavétellel és ötnapos köztes intervallummal felvett minta $(N=23$; átlagéletkor 42 év, szórás 12 év; 8 férfi, 15 nô) adatai alapján a méróeszköz teszt-reteszt megbízhatósága is elfogadhatónak mutatkozott $(\mathrm{r}=0,65$; $\mathrm{p}<0,001)$. Az item-analízisben az item-maradék korrelációk 0,56 és 0,73 között mozogtak. A méróeszköz rotálatlan fókomponens-elemzése is megerôsítette a kérdôív homogenitását, az egyetlen, egynél nagyobb sajátértékú komponens által magyarázott variancia elérte a 62,1\%-ot; az egyes tételek töltése e komponensen pedig 0,71 és 0,85 közöttinek bizonyult (1. táblázat).

1. táblázat. A WHO Általános Jól-lét Skála tételeinek leíró jellemzói (a skála számértékei 0 és 3 között változtak)

\begin{tabular}{|l|c|c|c|c|}
\hline $\mathrm{N}=12391$ & $\begin{array}{c}\text { Tételek töltése a } \\
\text { fókomponensen }\end{array}$ & $\begin{array}{c}\text { Item-maradék } \\
\text { korrelációk }\end{array}$ & Átlag* & Szórás \\
\hline 1. tétel & 0,85 & 0,72 & 1,74 & 0,97 \\
\hline 2. tétel & 0,84 & 0,69 & 1,56 & 0,97 \\
\hline 3. tétel & 0,82 & 0,73 & 1,71 & 0,94 \\
\hline 4. tétel & 0,72 & 0,57 & 1,33 & 0,97 \\
\hline 5. tétel & 0,71 & 0,56 & 1,41 & 0,99 \\
\hline
\end{tabular}

Mintánkban az Általános Jól-lét Skálán a férfiak szignifikánsan ( $\mathrm{t}=$ 11,2; $\mathrm{p}<0,001)$, de csak kis mértékben (Cohen-d =0,21) magasabb pontszámot értek el a nóknél (2. táblázat). 
2. táblázat. A WHO Általános Jól-lét Skála átlaga, szórása és belsố megbízhatósága mintánkban

\begin{tabular}{|c|c|c|c|c|c|c|c|}
\hline \multicolumn{2}{|c|}{ Nók $(\mathrm{N}=6854)$} & \multicolumn{2}{|c|}{ Férfiak $(\mathrm{N}=5522)$} & \multicolumn{4}{|c|}{ Teljes minta $(\mathrm{N}=12391)^{*}$} \\
\hline Átlag & Szórás & Átlag & Szórás & Átlag & Szórás & $\begin{array}{c}\text { Tételek } \\
\text { száma }\end{array}$ & $\begin{array}{c}\text { Cronbach- } \\
\text { alfa }\end{array}$ \\
\hline 7,4 & 3,8 & 8,2 & 3,7 & 7,8 & 3,8 & 5 & 0,85 \\
\hline
\end{tabular}

*15 fố nem adta meg a nemét

Életkor tekintetében a válaszadókat három csoportra bontottuk: 1844 évesekre, 45-64 évesekre és 65 év felettiekre (3. táblázat). Vizsgált kérdőívünkön e csoportok különbözó értékeket értek el ( $F=271,2 ; p<0,001)$; mégpedig a kor növekedésével a jóllét hanyatlása járt együtt. A különbség mind a 18-44 és 45-64 évesek közt (Cohen-d = 0,33), mind ez utóbbiak és a 65 év felettiek közt (Cohen-d $=0,19)$ kicsi, azonban a két szélsó korcsoport között már közepes erősségú (Cohen-d = 0,54).

3. táblázat. A WHO Általános Jól-lét Skála átlaga, szórása életkori csoportok szerint

\begin{tabular}{|c|c|c|c|c|c|}
\hline \multicolumn{2}{|c|}{ 18-44 évesek $(\mathrm{N}=5672)$} & \multicolumn{2}{|c|}{ 45-64 évesek $(\mathrm{N}=4202)$} & \multicolumn{2}{c|}{65 év felettiek $(\mathrm{N}=2498)$} \\
\hline Átlag & Szórás & Átlag & Szórás & Átlag & Szórás \\
\hline 8,5 & 3,4 & 7,4 & 4,0 & 6,6 & 4,0 \\
\hline
\end{tabular}

(Megjegyzés: 19 fố nem adta meg az életkorát)

Iskolázottság tekintetében négy részre osztottuk a vizsgálat résztvevőit: 8 általános iskolai vagy az alatti végzettséggel rendelkezókre, szakmunkásokra, szakközépiskolai vagy gimnáziumi érettségivel rendelkezókre és főiskolát vagy egyetemet végzettekre (4. táblázat). A csoportok között itt is szignifikáns eltérést $(F=185 ; p<0,001)$ mutattak az adatok, mégpedig az elvárásoknak megfelelően mindig a magasabb iskolai végzettségúek javára. A post hoc (Bonferroni) elemzés szerint az egyes szomszédos csoportok közötti különbség is minden esetben szignifikáns $(\mathrm{p}<0,001)$ volt, bár az eltérés egyik estben sem haladta meg a csekély mértéket (a Cohen-d a csoportok táblázatunk szerinti sorrendjében rendre 0,31; 0,12 és 0,16 volt). Az általános iskolai végzettséggel vagy azzal sem rendelkezók és a felsófokú végzettségúek között a különbség viszont már közepes méretúnek mutatkozott (Cohen-d $=0,57$ ).

A fenti eredmények okán a további elemzésekben célváltozóink kap-

4. táblázat. A WHO Általános Jól-lét Skála átlaga, szórása iskolázottsági csoportok szerint

\begin{tabular}{|c|c|c|c|c|c|c|c|}
\hline \multicolumn{2}{|c|}{$\begin{array}{c}8 \text { általános vagy } \\
\text { az alatt }(\mathrm{N}=3723)\end{array}$} & \multicolumn{2}{|c|}{$\begin{array}{c}\text { Szakmunkás } \\
(\mathrm{N}=3129)\end{array}$} & \multicolumn{2}{c|}{$\begin{array}{c}\text { Szakközépiskola vagy } \\
\text { gimnázium }(\mathrm{N}=3746)\end{array}$} & \multicolumn{2}{|c|}{$\begin{array}{c}\text { Fóiskola vagy } \\
\text { egyetem }(\mathrm{N}=1729)\end{array}$} \\
\hline Átlag & Szórás & Átlag & Szórás & Átlag & Szórás & Átlag & Szórás \\
\hline 6,7 & 4,0 & 7,8 & 3,6 & 8,3 & 3,6 & 8,8 & 3,4 \\
\hline
\end{tabular}


csolatvizsgálatát mindig a nem, az életkor és az iskolai végzettség kontrollálásával végeztük el.

A WHO Általános Jól-lét Skálája közepesen erôs, negatív kapcsolatban $(\mathrm{r}=-0.43 ; \mathrm{p}<0.001)$ állt mintánkban mind a Rövidített Beck Depresszió Kérdóív értékével, mind a Kórházi Szorongás Skála (HAS) összpontszámával $(\mathrm{r}=-0,47 ; \mathrm{p}<0,001)$, mind a vitális kimerültséggel $(\mathrm{r}=$ $-0,52 ; \mathrm{p}<0,001)$ és a reménytelenséggel $(\mathrm{r}=-0,37 ; \mathrm{p}<0,001)$.

Hasonló erôsségú, pozitív kapcsolatban állt viszont vizsgált kérdőívünk összpontszáma mind a válaszadó önmagához $(\mathrm{r}=0,39 ; \mathrm{p}<0,001)$, mind másokhoz viszonyított $(\mathrm{r}=0,33 ; \mathrm{p}<0,001)$ szubjektív egészségi állapotára vonatkozó kérdésünkre adott válaszpontszámmal, továbbá az élet értelme-konstruktummal $(\mathrm{r}=0,36 ; \mathrm{p}<0,001)$. Vizsgált változóink egymással való összes kapcsolatát az 5. táblázat tartalmazza.

5. táblázat. Vizsgált változóink parciális korrelációs együtthatói a nem, a kor és az iskolai végzettség kontrollálásával

\begin{tabular}{|c|c|c|c|c|c|c|c|}
\hline & BDI_9 & HAS & Meaning & Egall_1 & Egall_2 & VEQ & Hopl. \\
\hline WHO_5 & -0.43 & -0.47 & 0.36 & 0.39 & 0.33 & -0.52 & -0.37 \\
\hline BDI_9 & & 0.65 & -0.28 & -0.40 & -0.33 & 0.62 & 0.71 \\
\hline HAS & & & -0.23 & -0.35 & -0.27 & 0.63 & 0.54 \\
\hline Meaning & & & & 0.18 & 0.17 & -0.28 & -0.32 \\
\hline Egall_1 & & & & 0.61 & -0.46 & -0.33 \\
\hline Egall_2 & & & & & & -0.37 & -0.27 \\
\hline VEQ & & & & & & & 0.54 \\
\hline
\end{tabular}

BDI_9: depresszió; HAS: szorongás; Meaning: élet értelme; VEQ: vitális kimerültség;

Egall_1: szubjektív egészségi állapot; Egall_2: szubjektív egészségi állapot másokhoz képest; Hopl: reménytelenség. Az összes feltüntetett kapcsolatnál p<0,001

\section{MEGBESZÉLÉS}

A felnőtt magyar népesség körében felvett, országos reprezentatív mintán elemzett WHO Jól-lét Kérdôív tételeinek belsố konzisztenciája kiváló. A mérôeszköz rotálatlan fókomponens-elemzése is megerósítette a kérdőív homogenitását. A kérdőív az elvárásoknak megfelelően közepesen erós, negatív kapcsolatban állt mind a Rövidített Beck Depresszió Kérdôív értékével, mind Kórházi Szorongás Skála összpontszámával és a reménytelenséggel. Kérdôívünk összpontszáma hasonló erôsségú, pozitív kapcsolatban állt mind a válaszadó önmagához, mind másokhoz viszonyított szubjektív egészségi állapotával, továbbá az élet értelmekonstruktummal. A kérdôív magyar változata megbízható és érvényes méróeszköznek tekinthetó a pozitív életminóség vizsgálatakor. 


\section{MELLÉKLET}

\section{Az 5 tételes WHO Jól-lét Kérdőív (WHO Well-Being Questionnaire) magyar változata}

Kérjük, karikázza be azt a válaszlehetôséget, mely legjobban leírja, hogyan érezte magát az elmúlt 2 hét során.

\begin{tabular}{|l|c|c|c|c|}
\hline Az elmúlt két hét során érezte-e magát & $\begin{array}{c}\text { egyáltalán } \\
\text { nem } \\
\text { jellemzó }\end{array}$ & $\begin{array}{c}\text { alig } \\
\text { jellemzó }\end{array}$ & jellemző & $\begin{array}{c}\text { teljesen } \\
\text { jellemzó }\end{array}$ \\
\hline $1 . \ldots$ vidámnak és jókedvúnek? & 0 & 1 & 2 & 3 \\
\hline 2. ... nyugodtnak és ellazultnak? & 0 & 1 & 2 & 3 \\
\hline 3... aktívnak és élénknek? & 0 & 1 & 2 & 3 \\
\hline $4 . \ldots$ ébredéskor frissnek és élénknek? & 0 & 1 & 2 & 3 \\
\hline $\begin{array}{l}\text { 5. A napjai tele voltak számára érdekes } \\
\text { dolgokkal? }\end{array}$ & 0 & 1 & 2 & 3 \\
\hline
\end{tabular}

\section{IRODALOM}

Bagés, N., Appels, A., Falger, P. R. J. (1999): Vital exhaustion as a risk factor of myocardial infarction: a case-control study in Venezuela. International Journal of Behavioral Medicine, 6 (3): 279-291.

Bagés, N., Falger, P. R. J., Pérez, M. G., Appels, A. (2000): Vital exhaustion measures and their associations with coronary heart disease risk factors in a sample of Spanishspeakers. Psychology and Health, 15 (6): 787-799.

Bech, P. (1966): The Bech, Hamilton and Zung Scales for Mood Disorders: Screening and Listening. 2nd ed. Springer, Berlin.

Bech, P., Staehr-Johansen, K., Gudex, C. (1996): The WHO (Ten) Well-Being Index: validation in diabetes. Psychotherapy and Psychosomatics, 65: 183-190.

Beck, A. T., Weissman, A., Lester, D., Trexler, L. (1974): The measurement of pessimism: the Hopelessness Scale. Journal of Consulting and Clinical Psychology, 42: 861-865.

Herrmann, Ch. (1997): International experiences with the Hospital Anxiety and Depression Scale. A review of validation data and clinical results. Journal of Psychosomatic Research, 42(1): 17-41.

Idler, E. L., Benyamini, Y. (1997): Self-rated health and mortality: a review of twentyseven community studies. Journal of Health and Social Behavior, 38 (1): 21-37.

Kopp, M. S., Skrabski, Á., Szedmák., S. (1998): Depressive symptomatology and vital exhaustion are differentially related to behavioural risk factors for coronary artery disease. Psychosomatic Medicine, 60: 752-758.

Perczel-Forintos D., Sallai J., Rózsa S. (2001): A Beck-féle Reménytelenség Skála pszichometriai vizsgálata. Psychiatria Hungarica, 16 (6): 632-643.

Rahe, R. H., Tolles, R. L. (2002): The Brief Stress and Coping Inventory: a useful stress management instrument. International Journal of Stress Management, 9 (2): 61-70.

Rózsa S., Kỏ N., Csoboth Cs., Purebl Gy., Beöthy-Molnár A., Szebik I., Berghammer R., 
Réthelyi J., Skrabski Á., Kopp M. (2005): Stressz és megküzdés. A Rahe-féle Rövidített Stressz és Megküzdés Kérdőívvel szerzett hazai eredmények ismertetése. Mentálhigiéné és Pszichoszomatika, 6 (4): 275-294.

Rózsa S., Réthelyi J., Stauder A., Susásnszky É., Mészáros E. (2003): A Hungarostudy 2002 országos reprezentatív felmérés általános módszertana és a felhasznált tesztbattéria pszichometriai jellemzói. Psychiatria Hungarica, 18 (2): 83-94.

Rózsa S., Szádóczky E., Füredi J. (2001): A Beck Depresszió Kérdôív rövidített változatának jellemzői hazai mintán. Psychiatria Hungarica, 16 (4): 384-402.

Zigmond, A. S., Snaith, R. P. (1983): The Hospital Anxiety and Depression Scale. Acta Psychiatrica Scandinavica, 67 (6): 361-370.

A tanulmány elkészitését segitố támogatások. A tanulmány az OTKA TS-40889 (2002), TS-049785 (2004) pályázatok, valamint az NKFP 1/002/2001 és az NKFP 1b/020/2004 támogatásával készült.

\section{SUSÁNSZKY, ÉVA - KONKOLŸ THEGE, BARNA - STAUDER, ADRIENNE - KOPP, MÁRIA \\ VALIDATION OF THE SHORT (5-ITEM) VERSION \\ OF THE WHO WELL-BEING SCALE BASED \\ ON A HUNGARIAN REPRESENTATIVE HEALTH SURVEY (HUNGAROSTUDY 2002)}

In this study we present the Hungarian adaptation of the shortened, 5-item version of the WHO Well-Being Index (WBI-5). The validation of the questionnaire was done on the basis of the Hungarostudy 2002 national representative health survey. 12,668 persons participated in the study, the sample was representative for the adult Hungarian population according to age, gender and place of residence. For the cross-validation of the questionnaire we used the Shortened Beck Depression Inventory (BDI), 3 items of the Beck Hopelessness Scale, the Anxiety subscale of the Hospital Anxiety and Depression Scale (HAS), the shortened Maastricht Vital Exhaustion Questionnaire, 7 items of the Life Meaning and relationships subscale of the Brief Stress and Coping Inventory, and self-rated health. The internal consistency of the 5-item WHO Well-Being Index was excellent (Cronbach-alpha: 0.85). The unrotated main component analysis also confirmed the homogenity of the instrument. As expected the questionnaire was in moderately strong, inverse correlation both with anxiety and depressive symptoms (BDI and HAS scores) as well as with vital exhaustion and hopelessness. WBI-5 showed moderately strong, positive correlation with self-rated health, compared to self and to others and also with life meaning score. We can conclude that the Hungarian version of the short WHO Well-Being Index is a reliable and valid instrument to measure positive quality of life.

Keywords: WHO Well-Being Index, Hungarostudy 2002 representative health survey 